\title{
と畜場における牛および豚枝肉の衛生状況
}

\author{
森田幸雄 ${ }^{* 1,}$ ・古茂田恵美子*1 ・塩 飽二 郎*2・細 見 隆 夫*2 \\ 板垣 基 樹*2 中田恵三*2 中井博康*2 ・渡邊昭 三*2 \\ 小澤邦寿*3 ・山本茂貴*4 $・$ 木村博 一 ${ }^{* 5}$ \\ $\left(* 1\right.$ 東京家政大学, ${ }^{* 2}$ (財) 日本食肉生産技術開発セン夕ー, *3 群馬県衛生環境研究所, \\ $* 4$ 国立医薬品食品衛生研究所, $* 5$ 国立感染症研究所感染症情報センター） \\ (受付 平成 21 年 12 月 11 日) \\ (受理 平成 22 年 5 月 11 日)
}

\section{Contamination of Cattle and Pig Carcasses in Abattoir in Japan}

\author{
Yukio Morita ${ }^{* 1,}{ }^{\dagger}$, Emiko Komoda*1, Jiro Shiwaku*2, Takao Hosomi*2, \\ Motoki Itagaki*2, Keizo Nakata*2, Hiroyasu Nakai*2, Syozo Watanabe*2, \\ Kunihisa Kozawa ${ }^{* 3}$, Shigeki Yamamoto*4 and Hirokazu Kimura*5 \\ (*1 Tokyo Kasei University, Kaga, Itabashi-ku,Tokyo $173-8602 ;{ }^{\dagger}$ Corresponding author) \\ (*2 Japan Meat Technology Institute, Akasaka, Minato-ku,Tokyo 107-0052) \\ (*3 Gunma Prefectural Institute of Public Health and Environmental Sciences, \\ Kamioki, Maebashi, Gunma 371-0052) \\ (*4 National Institute of Health Science, Kamiyouga, Setagaya-ku, Tokyo 158-8501) \\ $\left({ }^{* 5}\right.$ National Institute of Infectious Disease, Infectious Disease Surveillance Center, \\ Gakuen, Musashimurayama-shi, Tokyo 208-0011)
}

はじめに

平成 8 年度に日本全国で発生した腸管出血性大腸菌 (EHEC) 感染症やその後のさまざまな食品由来感染症の 流行対策として, と畜場法や食品衛生法等の食肉衛生関 連法令の改正が実施された。これらの対策によりと畜場 内では八ード・ソフト両面からの衛生向上に向けた取り 組みが実施され, わが国の食肉の衛生状況は格段に向上 したと思われる。

さらに, 米国の基準に沿った HACCP の導入が平成 11 年から導入されている対米国食肉輸出認定処理場 (平成 21 年 12 月現在, 4 力所) や, HACCP 手法を用い た衛生管理を基本とした ISO 22000 を取得した食肉処 理場屯稼働している.

そこで, 対米国食肉輸出認定処理場や ISO22000を取
得した処理場も含めた全国 7 力所の食肉処理場で生産 されている牛おょび豚枝肉について統一した方法でふき 取り検查を実施し, 食肉の衛生状況を比較した。

\section{材料および方法}

2008 年の夏季（7月 15 日〜8 月 26 日）抢よび 2009 年の冬季（1月 14 日〜2月 24 日）について, 牛食肉処 理場 7 施設（処理場 $A \sim G$ ） 之豚食肉処理場 6 施設（処 理場 $A, C \sim G)$ の枝肉についてふき取り検查を実施し た。なお，処理場 A と B は ISO22000 取得食肉処理場 (以下,「ISO 取得処理場」)， C と D は牛の処理のみが対 米国輸出認定食肉処理場 (以下, 「対米認定処理場」), $\mathrm{E}$, $\mathrm{F}, \mathrm{G}$ は前述のいずれも取得していない処理場（以下， 「未取得処理場」)であった。

枝肉のふき取り方法は米国連邦食肉検査規則の微生物

\footnotetext{
$\dagger$ 連絡先

*1 昰173-8602 東京都板橋区加賀 1-18-1

*2 雪107-0052 東京都港区赤坂 6-13-16

*3 函371-0052 前橋市上沖町 378

*4 恶158-8501 東京都世田谷区上用賀 1-18-1

*5 焉208-0011 武蔵村山市学園 4-7-1
} 
検体：之畜処理後 12 時間以上 27 時間以内の保冷と体

牛は肛門周囲，腹部，胸部，豚は肛門周囲，胸部， 頸部の $100 \mathrm{~cm}^{2}$ を採取

採取は, 各々, 緩衝ペプトン水 $(\mathrm{BPW})$ を $10 \mathrm{~m} l$ 入れた Whirl-Pak のスポンジで滅菌 $100 \mathrm{~cm}^{2}$ 枠内を水平・垂直方向にそれぞれ 10 回ずつふき取り

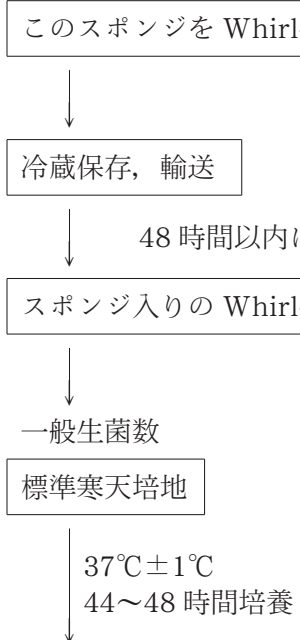

菌数測定
菌数測定
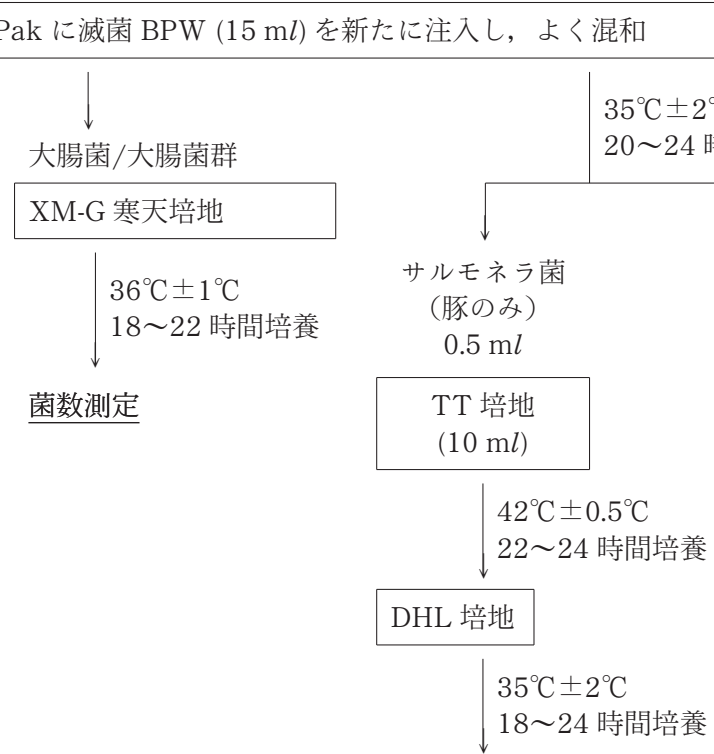

発育集落の観察・同定 $5^{\circ} \mathrm{C} \pm 2{ }^{\circ} \mathrm{C}$

２4 時間培養

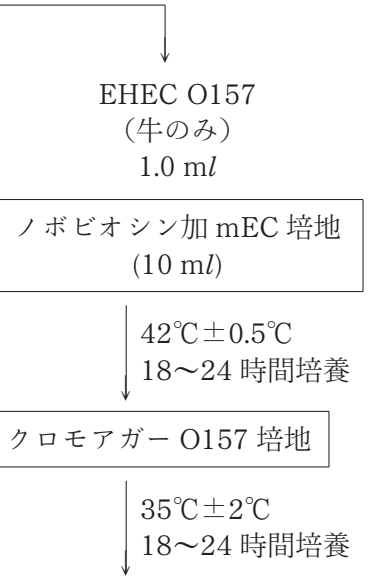

発育集落の観察・同定

図 1 . 培養方法

制御：HACCP システム Federal Register, Final Rule (http:/ / www.fsis.usda.gov / OPPDE/rdad/FRPubs / 93-016F.pdf) のスポンジ法に準拠して実施した。検体は と畜処理後 12 時間以上 27 時間以内の保冷と体とし, 牛は肛門周囲, 腹部および胸部, 豚は肛門周囲, 胸部お よび頸部の $100 \mathrm{~cm}^{2}$ を採取した。採取は，それぞれ緩衝 ペプトン水 (BPW: Oxoid)を $10 \mathrm{~m} l$ 入れた Whirl-Pak (Nasco)のスポンジで滅菌 $100 \mathrm{~cm}^{2}$ 枠（日水）内を水 平・垂直方向にそれぞれ 10 回ずつふき取った。このス ポンジを Whirl-Pak に戻し, 冷蔵保存輸送し 48 時間以 内に検査に供した。検査はスポンジ入りの Whirl-Pak に滅菌 BPW $(15 \mathrm{ml})$ を新たに注入し, よく混和後, 一般 生菌数 (標準寒天培地: 日水), 大腸菌群数 - 大腸菌数 (XM-G 培地：日水) を混釈培養法で求めた。 さらに, 牛 ふき取り検体は腸管出血性大腸菌 (EHEC) O157 の, 豚 ふき取り検体はサルモネラの分離・同定検査を実施し た. EHEC O157 はノボビオシン加 mEC 培地 (栄研) で 増菌後, クロモアーガーO157 (CHROMagar) で, サル モネラはテトラチオネート (TT) 培地 (Oxoid) で増菌培
養後，DHL 寒天培地（日水）で分離を行った（図 1).

体表 $100 \mathrm{~cm}^{2}$ を約 $25 \mathrm{ml}$ の $\mathrm{BPW}$ でふき取ることか ら, 混釈培養で $1 \mathrm{ml}\left(4 \mathrm{~cm}^{2}\right)$ 当たり $<30$ 個であるなら, 検出限界值は $<7.5$ 個 $/ \mathrm{cm}^{2}$ となる計算であるが，検出菌 数が極めて少数の検体ああることから, BPW $1 \mathrm{~m} l$ 接種 の混釈培養の平板に出現した $0 \sim 30$ 個の集落について 屯カウントし $1 \mathrm{~m} l$ 当たりの菌数を求めた後, 4 で割り 1 $\mathrm{cm}^{2}$ 当たりの菌数を算出した.

統計処理は, 検出率などの差については $\chi^{2}$ 検定 (サン プル数 5 以下の場合は Yates の補正で実施）によって, 一般生菌数の比較については菌数の対数值を分散分析に よって，有意差を求めた。

結果

\section{牛の EHEC 0157 検査・豚のサルモネラ検査結果}

EHECO157 は牛の 7 処理場のいずれの検体からむ, サルモネラは豚の 6 処理場のいずれの検体からむ検出 されなかった。 
表 1. 牛の処理場別の大腸菌および大腸菌群検出枝肉の割合と菌数

\begin{tabular}{|c|c|c|c|c|c|c|c|c|c|c|c|}
\hline \multirow{3}{*}{$\begin{array}{l}\text { 菌 } \\
\text { 種 } \\
\text { 等 }\end{array}$} & \multirow{3}{*}{ 処理場名 } & \multicolumn{10}{|c|}{ 検出枝肉数/調査枝肉数 } \\
\hline & & \multicolumn{4}{|c|}{ 夏季 $(7 / 15 \sim 8 / 26)$} & \multicolumn{4}{|c|}{ 冬季 $(1 / 14 \sim 2 / 24)$} & \multirow{2}{*}{$\begin{array}{l}\text { 処理場ごとの } \\
\text { 夏・冬全体 }^{\mathrm{a})}\end{array}$} & \multirow{2}{*}{$\begin{array}{c}\text { 条件ごとの } \\
{\text { 全体 }{ }^{\mathrm{a})}}\end{array}$} \\
\hline & & $\begin{array}{l}\text { 肛門 } \\
\text { 周囲 }\end{array}$ & 腹部 & 胸部 & $\begin{array}{l}\text { 夏季 } \\
\text { 全体 }^{\text {a) }}\end{array}$ & $\begin{array}{l}\text { 肚門 } \\
\text { 周囲 }\end{array}$ & 腹部 & 胸部 & $\begin{array}{l}\text { 冬季 } \\
\text { 全体 }{ }^{\mathrm{a})}\end{array}$ & & \\
\hline \multirow{9}{*}{$\begin{array}{l}\text { 大 } \\
\text { 腸 } \\
\text { 菌 }\end{array}$} & $\mathrm{A}$ & $0 / 10$ & $0 / 10$ & $0 / 10$ & $0 / 10$ & $0 / 10$ & $0 / 10$ & $0 / 10$ & $0 / 10$ & $0 / 20$ & \multirow{2}{*}{$0 / 40$} \\
\hline & B & $0 / 10$ & $0 / 10$ & $0 / 10$ & $0 / 10$ & $0 / 10$ & $0 / 10$ & $0 / 10$ & $0 / 10$ & $0 / 20$ & \\
\hline & $\mathrm{C}$ & $1 / 10$ & $1 / 10$ & $0 / 10$ & $2 / 10$ & $0 / 10$ & $0 / 10$ & $2 / 10$ & $2 / 10$ & $4 / 20$ & \multirow{2}{*}{$5 / 40$} \\
\hline & $\mathrm{D}$ & $1 / 10$ & $1 / 10$ & $0 / 10$ & $1 / 10$ & $0 / 10$ & $0 / 10$ & $0 / 10$ & $0 / 10$ & $1 / 20$ & \\
\hline & $\mathrm{E}$ & $4 / 10$ & $4 / 10$ & $4 / 10$ & $9 / 10$ & $0 / 10$ & $1 / 10$ & $0 / 10$ & $1 / 10$ & $10 / 20^{\mathrm{b})}$ & \multirow{3}{*}{$12 / 60$} \\
\hline & $\mathrm{F}$ & $0 / 10$ & $0 / 10$ & $0 / 10$ & $0 / 10$ & $0 / 10$ & $0 / 10$ & $0 / 10$ & $0 / 10$ & $0 / 20$ & \\
\hline & G & $0 / 10$ & $2 / 10$ & $0 / 10$ & $2 / 10$ & $0 / 10$ & $0 / 10$ & $0 / 10$ & $0 / 10$ & $2 / 20$ & \\
\hline & 計 & $6 / 70^{\mathrm{c})}$ & $8 / 70^{c)}$ & $4 / 70$ & $14 / 70^{\mathrm{d})}$ & $0 / 70^{\text {c) }}$ & $1 / 70^{\mathrm{c})}$ & $2 / 70$ & $3 / 70^{\mathrm{d})}$ & $17 / 140$ & $17 / 140$ \\
\hline & $\begin{array}{c}\text { 検出した枝肉の } \\
\text { 大腸菌数の範囲 } \\
\left(\mathrm{cfu} / \mathrm{cm}^{2}\right)\end{array}$ & $0.3 \sim 0.5$ & $0.3 \sim 7.5$ & $0.3 \sim 0.5$ & $0.3 \sim 7.5$ & —e) & 0.5 & $0.3 \sim 1.0$ & $0.3 \sim 1.0$ & $0.3 \sim 7.5$ & $0.3 \sim 7.5$ \\
\hline \multirow{8}{*}{$\begin{array}{l}\text { 大 } \\
\text { 腸 } \\
\text { 菌 } \\
\text { 群 }\end{array}$} & $\mathrm{A}$ & $1 / 10$ & $0 / 10$ & $0 / 10$ & $1 / 10$ & $6 / 10$ & $0 / 10$ & $0 / 10$ & $6 / 10$ & $7 / 20$ & \multirow{2}{*}{$9 / 40^{g)}$} \\
\hline & $\mathrm{B}$ & $0 / 10$ & $0 / 10$ & $1 / 10$ & $1 / 10$ & $0 / 10$ & $0 / 10$ & $1 / 10$ & $1 / 10$ & $2 / 20^{\mathrm{f})}$ & \\
\hline & $\mathrm{C}$ & $3 / 10$ & $5 / 10$ & $3 / 10$ & $7 / 10$ & $2 / 10$ & $2 / 10$ & $4 / 10$ & $6 / 10$ & $13 / 20$ & \multirow{2}{*}{$21 / 40$} \\
\hline & $\mathrm{D}$ & $3 / 10$ & $1 / 10$ & $2 / 10$ & $4 / 10$ & $1 / 10$ & $0 / 10$ & $3 / 10$ & $4 / 10$ & $8 / 20$ & \\
\hline & $\mathrm{E}$ & $8 / 10$ & $5 / 10$ & $5 / 10$ & $10 / 10$ & $0 / 10$ & $3 / 10$ & $1 / 10$ & $3 / 10$ & $13 / 20$ & \multirow{3}{*}{$26 / 60$} \\
\hline & $\mathrm{F}$ & $1 / 10$ & $2 / 10$ & $1 / 10$ & $4 / 10$ & $0 / 10$ & $0 / 10$ & $2 / 10$ & $2 / 10$ & $6 / 20$ & \\
\hline & G & $3 / 10$ & $4 / 10$ & $2 / 10$ & $7 / 10$ & $0 / 10$ & $0 / 10$ & $0 / 10$ & $0 / 10$ & $7 / 20$ & \\
\hline & 計 & $19 / 70^{\mathrm{c})}$ & $17 / 70^{\mathrm{c})}$ & $14 / 70$ & $34 / 70$ & $9 / 70^{\text {c) }}$ & $5 / 70^{\mathrm{c})}$ & $11 / 70$ & $22 / 70$ & $56 / 140$ & $56 / 140$ \\
\hline
\end{tabular}

検出した枝肉の

大腸菌群数の範囲 $\quad 0.3 \sim 11.0 \quad 0.3 \sim 110.0 \quad 0.3 \sim 4.5 \quad 0.3 \sim 110.0 \quad 0.3 \sim 1.3 \quad 0.3 \sim 1.8 \quad 0.3 \sim 10.0 \quad 0.3 \sim 10.0 \quad 0.3 \sim 110.0 \quad 0.3 \sim 110.0$ $\left(\mathrm{cfu} / \mathrm{cm}^{2}\right)$

a) 肛門周囲，腹部，胸部のいずれかから該当菌が検出された枝肉頭数/調査枝肉数

b) $\mathrm{E}$ 処理場 $>\mathrm{A}, \mathrm{B}, \mathrm{D}, \mathrm{F}$ 処理場 $(p<0.01)$, G 処理場 $(p<0.05)$

c) 夏季 $>$ 冬季 $(p<0.05)$

d) 夏季 $>$ 冬季 $(p<0.01)$

e) 大腸菌が検出された枝肉が存在しないもの

f) B 処理場 $<\mathrm{C}, \mathrm{E}$ 処理場 $(p<0.05)$

g) ISO 取得処理場 $<$ 対米認定処理場 $(p<0.01)$, 未取得処理場 $(p<0.05)$

\section{牛の大腸菌および大腸菌群検査結果（表 1)}

大腸菌は ISO 取得処理場の A, B および未取得処理場 の $\mathrm{F}$ 処理場の牛枝肉からは検出されなかった. 対米認定 処理場 Cでは 20\% (4/20), D では 5\%(1/20)の牛枝肉 から検出された。未取得処理場のうち G 処理場では 10\%(2/20)の枝肉から検出されたが, E 処理場では $50 \%(10 / 20)$ の枝肉から検出され， A, B, D および F 処 理場 $(p<0.01)$ や $\mathrm{G}$ 処理場 $(p<0.05)$ に比べ有意に高い 検出割合を示した。 また， $\mathrm{E}$ 処理場の成績が大きく反映 される結果となったが, 夏季の肛門周囲, 腹部そして枝 肉全体の検出割合は冬季のそれらと比べて有意に高かっ た。 また, 肛門周囲, 腹部, 胸部の検出割合の有意差は 認められなかった。 大腸菌数は最高值が $7.5 \mathrm{cfu} / \mathrm{cm}^{2}$ で，E処理場において夏季に実施したと体の腹部が該当 検体であった。

大腸菌群は調査 7 処理場のすべてにおいて, 牛枝肉か ら 10\% (2/20)〜 65\% (13/20) の割合で検出された。B 処理場の検出割合 $(10 \%)$ は C および $\mathrm{E}$ 処理場の検出割
合 $(65 \%)$ に比べて有意に低かったが $(p<0.05)$ ，その他 の処理場との間で有意な差は認められなかった。 A 処理 場の冬季 (60\%) は夏季 $(10 \%)$ に比べて大腸菌群の検出 率が有意に高かったものの, $\mathrm{A} \sim \mathrm{G}$ 処理場全体の合計で みると, 夏季の肛門周囲 $(p<0.05)$, 腹部 $(p<0.05)$ での 大腸菌群の検出割合は冬季のそれらと比べて有意に高 かった。 また，大腸菌群数の最高值は $110.0 \mathrm{cfu} / \mathrm{cm}^{2}$ で あり,これは大腸菌が $7.5 \mathrm{cfu} / \mathrm{cm}^{2}$ 検出された $\mathrm{E}$ 処理場 の検体であった。

牛枝肉においては, ISO 取得処理場（A および B) の 成績が最も良好で, 大腸菌は未検出, 大腸菌群の検出割 合は 22.5\% (9/40)で対米認定処理場（Cおよび D) (52.5\%) ( G) $(43.3 \%)(p<0.05)$ と比べて有意に低い值を示した.

\section{豚の大腸菌および大腸菌群検査結果（表 2)}

大腸菌は ISO 取得処理場の A および未取得処理場の $\mathrm{G}$ 処理場の豚枝肉からは検出されなかったが，対米認定 処理場の C, D 処理場からは，それぞれ 10\%および $5 \%$ 
表 2. 豚の処理場別の大腸菌および大腸菌群検出枝肉の割合と菌数

\begin{tabular}{|c|c|c|c|c|c|c|c|c|c|c|c|}
\hline \multirow{3}{*}{$\begin{array}{l}\text { 菌 } \\
\text { 種 } \\
\text { 等 }\end{array}$} & \multirow{3}{*}{ 施設名 } & \multicolumn{10}{|c|}{ 検出枝肉数/調査枝肉数 } \\
\hline & & \multicolumn{4}{|c|}{ 夏季 $(7 / 15 \sim 8 / 26)$} & \multicolumn{4}{|c|}{ 冬季 $(1 / 14 \sim 2 / 24)$} & \multirow{2}{*}{$\begin{array}{c}\text { 処理場ごとの } \\
\text { 夏冬全体 }\end{array}$} & \multirow{2}{*}{$\begin{array}{c}\text { 条件ごとの } \\
\text { 全体 }^{\mathrm{a})}\end{array}$} \\
\hline & & $\begin{array}{l}\text { 肛門 } \\
\text { 周囲 }\end{array}$ & 胸部 & 頝部 & $\begin{array}{l}\text { 夏季 } \\
\text { 全体 }\end{array}$ & $\begin{array}{l}\text { 肛門 } \\
\text { 周囲 }\end{array}$ & 胸部 & 頝部 & $\begin{array}{l}\text { 冬季 } \\
\text { 全体 }\end{array}$ & & \\
\hline \multirow{7}{*}{$\begin{array}{l}\text { 腸 } \\
\text { 囷 }\end{array}$} & A & $0 / 10$ & $0 / 10$ & $0 / 10$ & $0 / 10$ & $0 / 10$ & $0 / 10$ & $0 / 10$ & $0 / 10$ & $0 / 20$ & $0 / 20$ \\
\hline & C & $0 / 10$ & $0 / 10$ & $1 / 10$ & $1 / 10$ & $0 / 10$ & $1 / 10$ & $0 / 10$ & $1 / 10$ & $2 / 20$ & \multirow{2}{*}{$3 / 40$} \\
\hline & $\mathrm{D}$ & $0 / 10$ & $0 / 10$ & $1 / 10$ & $1 / 10$ & $0 / 10$ & $0 / 10$ & $0 / 10$ & $0 / 10$ & $1 / 20$ & \\
\hline & $\mathrm{E}$ & $0 / 10$ & $0 / 10$ & $3 / 10$ & $3 / 10$ & $0 / 10$ & $0 / 10$ & $0 / 10$ & $0 / 10$ & $3 / 20$ & \multirow{3}{*}{$4 / 60$} \\
\hline & $\mathrm{F}$ & $0 / 10$ & $0 / 10$ & $1 / 10$ & $1 / 10$ & $0 / 10$ & $0 / 10$ & $0 / 10$ & $0 / 10$ & $1 / 20$ & \\
\hline & G & $0 / 10$ & $0 / 10$ & $0 / 10$ & $0 / 10$ & $0 / 10$ & $0 / 10$ & $0 / 10$ & $0 / 10$ & $0 / 20$ & \\
\hline & 計 & $0 / 60$ & $0 / 60$ & $6 / 60$ & $6 / 60$ & $0 / 60$ & $1 / 60$ & $0 / 60$ & $1 / 60$ & $7 / 120$ & $7 / 120$ \\
\hline
\end{tabular}

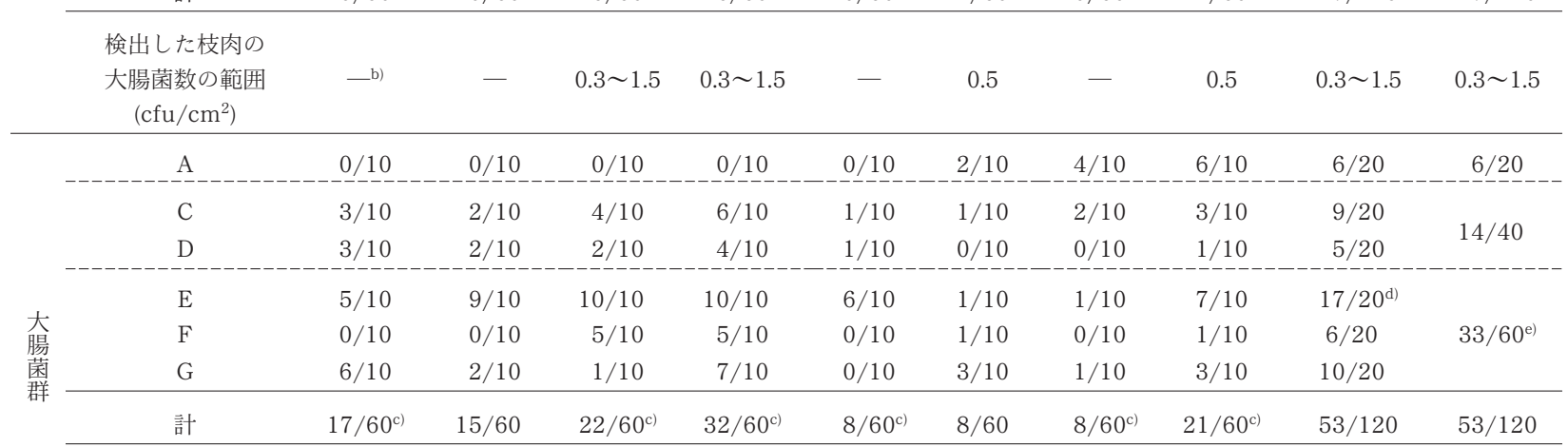

検出した枝肉の

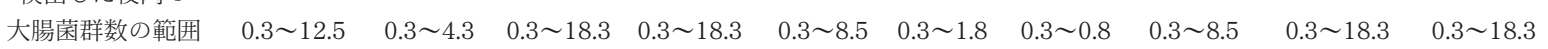
$\left(\mathrm{cfu} / \mathrm{cm}^{2}\right)$

a) 肛門周囲, 胸部, 頚部のいずれかから, 大腸菌群が検出された枝肉頭数/調査枝肉数

b) 大腸菌が検出された枝肉が存在しないむの

c) 夏季 $>$ 冬季 $(p<0.05)$

d) $\mathrm{E}$ 処理場 $>\mathrm{A}, \mathrm{C}, \mathrm{D}, \mathrm{F}$ 処理場 $(p<0.01)$, G 処理場 $(p<0.05)$

e) 未取得処理場 $>$ 対米認定処理場 $(p<0.05)$

の豚枝肉から, 未取得処理場の $\mathrm{E}$ 打よび $\mathrm{F}$ 処理場から は，それぞれ $15 \%$ 打よび $5 \%$ の枝肉から検出された。季 節および検查部位（肚門周囲，胸部，頝部）の間では大 腸菌の検出率に差は認められなかった。 大腸菌数の最高 值は $1.5 \mathrm{cfu} / \mathrm{cm}^{2}$ で, $\mathrm{F}$ 処理場において夏季に実施した と体の䅡部が該当検体であった。

大腸菌群は調査 6 処理場すべてにおいて, 豚枝肉から 25 85\%の割合で検出された。 $\mathrm{E}$ 処理場の枝肉からの 大腸菌群検出割合は $85 \%$ で, これは他の $\mathrm{A}, \mathrm{C}, \mathrm{D}, \mathrm{F}$ 処理 場 $(p<0.01)$ および $\mathrm{G}$ 処理場 $(p<0.05)$ 之比べ有意に高 い值であった。 その他の処理場間で検出率に差は認めら れなかった．A 処理場の冬季 (60\%) は夏季 $(0 \%)$ に比べ て大腸菌群の検出率が有意に高かったが, A から G 処 理場全体の合計でみると, 夏季の肛門周囲 $(p<0.01)$, 頚 部 $(p<0.01)$ 抢よび全体 $(p<0.01)$ の検出割合は冬季の それらと比べて有意に高かった。 大腸菌群数の最高值は $18.3 \mathrm{cfu} / \mathrm{cm}^{2}$ であり, これは大腸菌が $0.3 \mathrm{cfu} / \mathrm{cm}^{2}$ 検出 された $\mathrm{E}$ 処理場において夏季に実施したと体の䅡部が 該当検体であった。

豚枝肉に扔いても，牛枝肉之同様に ISO 取得処理場の $\mathrm{A}$ 処理場の成績が最も良好で, 大腸菌は未検出, 大腸菌
群の検出割合は $30 \%$ で，C および D 処理場 (35\%), E, F および $\mathrm{G}$ 処理場 (55\%) に比べると低い值であった。

\section{牛および豚の処理場別一般生菌数（表 3)}

ISO 取得処理場の A おうよび B 処理場の牛枝肉におけ る夏拉よび冬の一般生菌数の相乗平均菌数はそれぞれ 5.2 および $1.5 \mathrm{cfu} / \mathrm{cm}^{2}$ で, $\mathrm{A}$ および $\mathrm{B}$ 処理場の一般生 菌数の相乗平均菌数は, C, D, E, F 打よび $\mathrm{G}$ 施設 $(p<$ 0.01) よりも有意に低い值であった。また， A 処理場の みは冬季の相乗平均菌数が夏季よりも高かったが， C, D および $\mathrm{E}$ 処理場ならびに $\mathrm{A} \sim \mathrm{G}$ 処理場全体の合計の夏 季の枝肉ふき取りの相乗平均菌数は冬季のそれに比べ有 意に高い值であった ( $\mathrm{C}$ 処理場 $p<0.05$, その他は $p<$ 0.01 ).

豚枝肉の一般生菌数で最も低い值を示したのは未取得 処理施設の $\mathrm{F}$ 処理場で $11.0 \mathrm{cfu} / \mathrm{cm}^{2}$ であった。 また, 最も高い值を示したのは未取得場の E 処理場で 69.3 $\mathrm{cfu} / \mathrm{cm}^{2}$ で, $\mathrm{E}$ 処理場は他のすべての処理場よりも有意 に高い值であった $(p<0.01)$. 牛枝肉の成績とほぼ同様 に, $\mathrm{A}$ 処理場のみは冬季の相乗平均菌数が夏季よりも高 い值であったが， D および $\mathrm{E}$ 処理場 $(p<0.01)$ ならびに $\mathrm{A} \sim \mathrm{G}$ 処理場全体の合計の夏季の枝肉ふき取り $(p<$ 
表 3. 牛・豚の処理場・部位等の一般生菌数（相乗平均： $\mathrm{cfu} / \mathrm{cm}^{2}$ )

\begin{tabular}{|c|c|c|c|c|c|c|c|c|c|c|c|}
\hline \multirow[b]{2}{*}{ 畜種 } & \multirow[b]{2}{*}{ 施設名 } & \multicolumn{3}{|c|}{ 夏季 (7/15～8/26) } & \multirow{2}{*}{$\begin{array}{l}\text { 夏季 } \\
\text { 相乗平均 } \\
\text { 菌数 }\end{array}$} & \multicolumn{3}{|c|}{ 冬季 (1/14～2/24) } & \multirow{2}{*}{$\begin{array}{c}\text { 冬季 } \\
\text { 相乗平均 } \\
\text { 菌数 }\end{array}$} & \multirow{2}{*}{$\begin{array}{c}\text { 夏・冬 } \\
\text { 相乗平均 } \\
\text { 菌数 }\end{array}$} & \multirow{2}{*}{$\begin{array}{c}\text { 条件ごとの } \\
\text { 夏・冬 } \\
\text { 相乗平均菌数 }\end{array}$} \\
\hline & & 肛門周囲 & 腹部 & 胸部 & & 肛門周囲 & 腹部 & 胸部 & & & \\
\hline \multirow[t]{8}{*}{ 牛 } & $\mathrm{A}$ & 6.2 & 8.7 & 1.2 & 4.5 & 9.5 & 5.7 & 3.8 & 6.0 & $5.2^{\mathrm{a})}$ & \multirow{2}{*}{$2.9^{\mathrm{c})}$} \\
\hline & $\mathrm{B}$ & 0.6 & 5.5 & 0.7 & 1.5 & 0.7 & 2.5 & 1.3 & 1.5 & $1.5^{\mathrm{b})}$ & \\
\hline & $\mathrm{C}$ & 68.0 & 84.6 & 31.8 & 55.7 & 11.2 & 32.1 & 45.3 & $25.5^{\mathrm{d})}$ & 37.4 & \multirow{2}{*}{35.3} \\
\hline & $\mathrm{D}$ & 121.3 & 114.6 & 12.0 & 93.6 & 3.1 & 21.0 & 28.4 & $12.4^{\mathrm{e})}$ & 34.0 & \\
\hline & $\mathrm{E}$ & 51.7 & 154.0 & 190.3 & 107.7 & 19.7 & 4.6 & 37.3 & $15.1^{\mathrm{e})}$ & 40.9 & \multirow{3}{*}{27.2} \\
\hline & $\mathrm{F}$ & 14.0 & 58.4 & 12.0 & 29.0 & 16.5 & 10.4 & 19.8 & 15.2 & 20.2 & \\
\hline & G & 74.7 & 19.2 & 18.8 & 29.9 & 128.1 & 18.2 & 5.8 & 23.9 & 26.7 & \\
\hline & $\begin{array}{c}\mathrm{A} \sim \mathrm{G} \text { の相乗 } \\
\text { 平均菌数 }\end{array}$ & 26.1 & 38.1 & $14.0^{\mathrm{f})}$ & 23.9 & 11.0 & 9.8 & 12.2 & $11.0^{\mathrm{e})}$ & 16.2 & 16.2 \\
\hline \multirow[b]{2}{*}{ 畜種 } & \multirow[b]{2}{*}{ 施設名 } & \multicolumn{3}{|c|}{ 夏季 $(7 / 15 \sim 8 / 26)$} & 夏季 & \multicolumn{3}{|c|}{ 冬季 (1/14～2/24) } & \multirow{2}{*}{$\begin{array}{c}\text { 冬季 } \\
\text { 相乗平均 } \\
\text { 菌数 }\end{array}$} & \multirow{2}{*}{$\begin{array}{c}\text { 夏・冬 } \\
\text { 相乗平均 } \\
\text { 菌数 }\end{array}$} & \multirow{2}{*}{$\begin{array}{c}\text { 条件ごとの } \\
\text { 夏・冬 } \\
\text { 相乗平均菌数 }\end{array}$} \\
\hline & & 肚門周囲 & 胸部 & 頝部 & $\begin{array}{l}\text { 相乗平均 } \\
\text { 菌数 }\end{array}$ & 肛門周囲 & 胸部 & 頝部 & & & \\
\hline \multirow[t]{7}{*}{ 豚 } & A & 15.6 & 25.9 & 2.6 & 8.4 & 4.4 & 238.7 & 69.6 & $41.7^{\mathrm{g})}$ & 19.0 & 19.0 \\
\hline & $\mathrm{C}$ & 45.2 & 17.8 & 16.8 & 23.7 & 36.1 & 8.4 & 8.9 & 14.0 & 18.3 & \multirow{2}{*}{16.3} \\
\hline & $\mathrm{D}$ & 97.5 & 35.4 & 9.7 & 33.7 & 3.5 & 8.4 & 8.9 & $6.5^{\mathrm{e})}$ & 14.5 & \\
\hline & $\mathrm{E}$ & 102.5 & 316.0 & 125.4 & 156.0 & 43.6 & 14.5 & 25.1 & $31.7^{\mathrm{e}}$ & $69.3^{\mathrm{h})}$ & \multirow{3}{*}{$22.4^{\mathrm{i})}$} \\
\hline & $\mathrm{F}$ & 12.1 & 7.1 & 8.6 & 9.1 & 10.3 & 18.5 & 11.8 & 13.2 & 11.0 & \\
\hline & G & 34.3 & 24.9 & 8.4 & 19.4 & 19.9 & 27.9 & 4.3 & 13.4 & 16.2 & \\
\hline & $\begin{array}{l}\mathrm{A} \sim \mathrm{G} \text { の相乗 } \\
\text { 平均菌数 }\end{array}$ & 38.1 & 25.7 & $13.4^{\mathrm{j})}$ & 29.1 & 13.1 & $22.5^{\mathrm{k})}$ & 15.6 & $13.9^{\mathrm{d})}$ & 20.0 & 20.0 \\
\hline
\end{tabular}

a) A 処理場 $<$ C, D, E, F, G 処理場 $(p<0.01)$

b) B 処理場 $<$ C, D, E, F, G 処理場 $(p<0.01)$

c) ISO22000 取得処理場 $<$ 未取得処理場, 対米認定処理場 $(p<0.01)$

d) 冬季相乗平均 $<$ 夏季相乗平均 $(p<0.05)$

e) 冬季相乗平均 $<$ 夏季相乗平均 $(p<0.01)$

f) 胸部 $<$ 腹部 $(p<0.01)$

g) 冬季相乗平均 $>$ 夏季相乗平均 $(p<0.01)$

h) $\mathrm{E}$ 処理場 $>$ A, C, D, E, F, G 処理場 $(p<0.01)$

i) 未取得処理場 $>$ 対米認定処理場 $(p<0.05)$

j) 頚部 $<$ 肛門周囲 $(p<0.01)$, 胸部 $(p<0.05)$

k) 胸部 $>$ 肛門周囲, 頚部 $(p<0.05)$

0.05)の相乗平均菌数は冬季のそれに比べ有意に高い值 であった。

\section{ま と め}

$\mathrm{HACCP}$ システムでは生物学的危害である EHEC O157, サルモネラや大腸菌の検出の有無が最も的確な 衛生評価となる. 牛, 豚ともに ISO 取得処理場である A と B 処理場は EHEC O157, サルモネラおよび大腸菌の いずれも検出されず，最も衛生的な枝肉を生産している と思われた。

牛の枝肉の衛生では対米認定処理場や未取得処理場よ り ISO 取得処理場が最も良い成績であった。森田ら ${ }^{1)}$ 平成 11 年の HACCP 導入直後に対米認定処理場 D で 実施した細菌検査成績では, サルモネラ (204 検体), EHEC O157 (99 検体), 大腸菌 (32 検体) はすべて陰 性, 一般生菌数 (99 検体) の相乗平均值は $26.8 \mathrm{cfu} / \mathrm{cm}^{2}$
であった. 今回の牛対米認定処理場 D では大腸菌の検出 割合が 5\% (6/120) で，一般生菌数む $35.3 \mathrm{cfu} / \mathrm{cm}^{2}$ で あり，若干高い值を示しており，HACCP 導入直後より あ枝肉が若干であるが污染されていると思われる。ま た，大腸菌，大腸菌群検出割合ならびに一般生菌数にお いて，E 処理場において比較的高い值を示したものの， $\mathrm{F}$ および $\mathrm{G}$ 処理場では対米認定処理場とほぼ同様な成 績であり，未取得処理場においても対米認定処理場と同 様に微生物学的に衛生的な枝肉が生産されていることが 確認された。

豚の枝肉では大腸菌検出割合, 大腸菌検出数, 大腸菌 群検出割合, 大腸菌群数ともに ISO 取得場である A が 最あ良好であった. 未取得処理場である $\mathrm{E}$ 処理場は牛, 豚ともに大腸菌検出枝肉割合, 大腸菌群検出枝肉割合, 大腸菌群数等が他の処理場（A, C, D, F および G） と比 較し高い值を示したことから，処理場によっては比較的 
污染のある枝肉を生産する処理場がいまだ存在すること が判明した。

ISO22000 取得処理場である A 処理場を除く他の処 理場では牛, 豚ともに夏に生産される枝肉は冬のそれと 比べて，大腸菌および大腸菌群の検出割合ならびに一般 生菌数で高い值を示すあのが多かった， と畜処理作業場 所は一頭処理するごとにナイフやカッターなどの消毒の ため $83^{\circ} \mathrm{C}$ 以上の温湯を保持した消毒槽が近位にあり, 夏季は特に作業環境が高温・多湿となる。A 処理場はと 畜処理環境む比較的良好であるのに対し，その他の処理 場はこの夏季の作業環境は悪化していた。したがって, このと畜作業環境が, 手作業の多いと畜処理作業の効率 や衛生的な手技の遂行を妨げている可能性が考えられ た。

牛, 豚とも枝肉から大腸菌未検出処理場が存在し, 特 に ISO 取得処理場は最も衛生的な枝肉を生産している ことが判明した。一方, 大腸菌污染が認められた処理場 あ見られ, 食肉処理施設ごとに生産される枝肉の衛生度 が異なっていた. ISO 22000 処理場は 8 年以内に HACCP の概念の基に設計・建築され，また施設責任者 の強い衛生管理意志の基に ISO22000 が導入された. 対
米認定処理施設は平成 2 年より「対米輸出食肉を取扱う と畜場等の認定要綱」に沿った衛生管理を実施している が，当時の施設を改築し認定されている．未取得処理場 の E, F, G は国・県・市町および農業団体出資による第 三セクターであり, 特に $\mathrm{E}$ 処理場は数力所の老朽化した 処理場を一つにした会社組織で作業従事者の平均年齢む 比較的高い処理場であった。これらの背景が今回の細菌 検査成績の一部に影響を与えているものと推定された.

食肉処理は自動化が難しく，かつ熟練を要する。より 衛生的な食肉が, 多くの食肉処理場で生産されるため に，衛生管理手法や作業手技など，食肉処理場相互の情 報交換や作業従事者の技術交流などが望まれる。また， 各々の処理場でこのふき取り方法を用いた検査を実施 し, 自己の処理場の衛生度を確認することが望ましい。

\section{文献}

1）森田幸雄, 新井芳典, 嶋村真理, 鮫島昭子, 庄司和人, 清 水静一, 天田貴昌, 久保雅敏, 中林良雄, 中嶋 隆：之畜 処理におけるナイフの消毒時間の検討と HACCP システ 么導入食肉処理場の枝肉の衛生状況. 日獣会誌, 54, 387-390 (2001). 